\title{
Chapter 13 \\ The Making of a Bourgeois Antiquity: \\ Wilhelm von Humboldt and Greek History ${ }^{1}$
}

\author{
Stefan Rebenich
}

\begin{abstract}
The question "Where do we stand?" asked by Wilhelm von Humboldt in his review of the eighteenth century expresses a borderline experience around 1800, which lastingly influenced the perception of the past and the present in Germany. The main focus of the reception of antiquity shifted from Rome to Hellas. Individuals were meant to grasp Greek culture in its diversity and Greek character in its totality. The study of Greek history established a new conception of up bringing, education and scholarship, but also of nation, state, and society. The idealised Greek city-states were a pivotal point of reference and comparison for the definition of education, which is seminal to bourgeois society as a permanent process of self-perfection, for the description of the relationship between freedom and education, for the connection between individual, society and state, and for the discussion of principles of social organisation and structure. The study of classical antiquity was the main theme of neo-humanistic teaching - and an effective instrument of social exclusion in nineteenth-century class society. The historical upheaval in the study of antiquity, which was tangible in Germany around 1800, brought forth the concepts of both classical scholarship and bourgeois culture in the nineteenth century.
\end{abstract}

"Where do we stand?" asked Wilhelm von Humboldt in his review of the eighteenth century. "Which part of its long and arduous path has mankind covered? Is it on a course that leads to the final destination?"2 The text is more than just a glimpse of the past: it

1 The works of Wilhelm von Humboldt referred to in this essay are cited in accordance with his Gesammelte Schriften, vol. 1-17 published by the Royal Prussian Academy of Sciences (Königlich Preußische Akademie der Wissenschaften), Berlin 1903-1936 (reprinted 1967/68). Volume and page numbers follow the abbreviation GS. Volume and page numbers in brackets refer to the following anthology: Wilhelm von Humboldt, Werke in fünfBänden, eds. A. Flitner and K. Giel, Darmstadt 1960-1981 (various reprints). - An earlier version of this paper was published in LANIERI 2011: 119-137. I would like to thank Richard Brobson for his help with the translation.

2 Humboldt, "Das achtzehnte Jahrhundert", GS II, 1 (I, 376). 
expresses a borderline experience, around 1800, which had a profound influence on the perception of past and present in Germany.

Greek antiquity was rediscovered in the mid-eighteenth century. Greece became the foremost object of productive artistic reception. At the same time, the exclusionist vision of classical culture associated with nobility began to end $^{3}$ and the neo-humanist teaching at grammar schools and the scientific research at universities concentrated equally on the study of Greece and Rome. The ancients were no longer timeless models, but historicised paradigms for Wissenschaft, literature, and the arts. Their works were still regarded as perfect, but also as historically constituted and therefore specific. The new German image of antiquity was characterised by a latent tension between classical aesthetics and enlightening historicism, and shifted between the canonisation of an idealised image of antiquity, on the one hand, and the recognition of its interconnection with other cultures, on the other. These categories were paradigmatically articulated in the work of Wilhelm von Humboldt. The aristocratic pupil of the classicist Christian Gottlob Heyne from Göttingen made it possible for the hitherto aristocratic veneration of the classics to become a field of enquiry with a scientific basis, and enabled the academic study of antiquity to ascend to a common leading discipline, which lastingly shaped the values and the curriculum of the class called the bourgeoisie. But what was the bourgeoisie?

\section{Bourgeoisie: An Attempt at a Definition}

It has long been acknowledged that conventional social parameters such as birth, education, occupation, or economic resources are insufficient for attempts to define the bourgeoisie. A specific kind of lifestyle, a specific "culture" has to be added in order to reconcile the difference between the heterogeneity of social positions and the homogeneity of intellectual identities. ${ }^{4}$ Thus, the bourgeois society is a model of acculturation, and contemporary historical research has specified numerous values and behaviours that determine middle-class culture, citizen attitude, or simply the middle-class way of life (Bürgerlichkeit): education, individual freedom, personal interest, the development of personal talents, the organisation of society from within, an orientation toward the common good, creativity and rationality, a belief in progress, striving for material possessions, the family as a private sphere, the autonomy of literature, music, and the plastic arts, etc. ${ }^{5}$ Over the course of the nineteenth century, these values constituted a system of enduring behavioural arrangements in a way that, notwithstanding different social bases, the representatives of the bourgeoisie attained perfectly comparable lifestyles. In this context,

3 See WALther 1998.

4 See Lepsius 1987.

5 See the relevant passages in NipPerder 1998: vol. 1 and 2/1. See further Conze/KockA/Koselleck et al. 1985-1992; Hahn/Hein 2005; KocKa 1987; KocKa 1995; Lundgreen 2000; Maurer 1996; SCHUlz 2005; VIeRHaUS 1981. 
middle-class intellectuals became the most important impetus of bourgeois culture. They were that part of the middle class that founded its claim to social excellence on the possession of knowledge and on a lifestyle derived from this possession.

Current research mostly ignores the importance of European antiquity for the formation of the bourgeoisie, for the emergence of middle-class intellectuals, and for the genesis of a bourgeois culture as a whole. ${ }^{6}$ Yet as will be argued, in early nineteenth-century Germany, antiquity as a historiographical construct and as an idealised timeless projection contributed considerably to both the homogenisation of the bourgeoisie and the constitution of middle-class culture.

\section{The Institutional Framework}

The importance of Wilhelm von Humboldt for the nationalisation of the learned classes and for neo-humanist educational reform has long been the subject of debates in scholarly literature. In the eyes of some scholars, the few months that Humboldt worked as privy councillor and head of the section for cultural affairs and public education in the Prussian Ministry of the Interior, from February 1809 to April or June 1810, make him the most influential minister for education and cultural affairs in German history. ${ }^{7}$ Amid the collapse of Prussia, Humboldt demanded a reform of the school system, for which he fought in his two memoranda, the Königsberg and the Lithuanian plan for school organisation. ${ }^{8}$ Moreover, he advanced a successful application of the memoranda, which embraced ideas of Schelling, Schleiermacher and Fichte, in the foundation of Berlin University. It has been asserted that Humboldt, apart from "the certainly significant achievement of founding the university in Berlin," in effect "accomplished nothing of importance in life." ${ }^{\prime 10}$ Others have suggested that his attempt at reform comprised an episode without consequences, ${ }^{11}$ and it has been argued recently that the idea of a "Humboldt University" is, in fact, a late nineteenth and early twentieth-century invention. ${ }^{12}$

Admittedly, it is indisputable that there were divergences between Humboldt's conception of an educational ideal and its practical implementation; ${ }^{13}$ that reforms in the

6 See, for example, HeIN/Schulz 1996: 10, who state that the connection of antiquity and bourgeois culture will "not be treated as an independent topic in this volume."

7 See, for example, Berglar 2003: 81. On Humboldt's work at the Ministry of the Interior, see SWEET 1980: 3-106.

8 GS XIII, 259-283 (IV, 168-195).

9 Humboldt, "Über die innere und äußere Organisation der höheren wissenschaftlichen Anstalten in Berlin," GS X, 250-260 (IV, 255-266). See vOM BRuch 2001.

10 KAEHLER 1927: 242f.

11 MeNZE 1975: 47f.

12 PaletscheK 2002; PALETSCheK 2001.

13 BeNNJER 1995. 
fields of Wissenschaft and education took shape before Humboldt's reform:14 that older scholarly literature tended to idealise Humboldt; ${ }^{15}$ and that making the "Humboldt myth" topical was of exceptional importance in numerous educational and higher-educational policy crises. ${ }^{16}$ But it is also indisputable that Humboldt's reflections on the content and function of education and his ideas about the different kinds of teaching at schools and universities had a continuous effect after 1810, even beyond the scope of Cabinet politics. After Humboldt was appointed head of the newly founded section for cultural affairs and education in the Ministry of the Interior, he was able to exploit the euphoria for reform, which had prevailed in the devastated Prussian state after its military defeat. Leveraging this mood during his term of office, which lasted barely sixteen months, enabled Humboldt to give important impulses to the creation of a unified public school and university system, which reflected his ideas of a general education. Furthermore, he communicated his views to a large circle of friends by way of many personal as well as written contacts. ${ }^{17}$

For the purposes of this essay, it is particularly important that Humboldt's reform constituted a new understanding of antiquity. The historical point of reference that sustained his vision was Greek antiquity. ${ }^{18}$ In encountering Greece, Humboldt succeeded in bolstering the political demands of the bourgeoisie by means of his educational ideal, which amalgamated stimuli and notions of different provenance. As Georg Bollenbeck has aptly put it, Humboldt effectively defined Bildung, education, "as a general and harmonious development of an individual aptitude; as acquisition of the world from within without any specific purpose; as an unfinished process, result and standard mediated by 'culture."'19

\section{Antiquity and Bourgeois Culture}

\section{Perfectibility: Education as a Permanent Process of Self-Perfection}

Education was one of the central values of bourgeois culture. It facilitated the development of the individual and the progress of society. For Humboldt, the study of Greek antiquity helped the formation of the individual's personality, as in Greece there was to be found "an accomplished form," which "encouraged us to replicate it." Humboldt celebrated the Greeks' "refinement and accuracy of the mind," their "strength" and their "dynamic power of imagination," their "agility and liveliness of emotion," their "prolific genius for the plastic arts and poetry," their "noble freedom of convictions," their "agreeable unity

14 Neugebauter 1990.

15 See, for example, Spranger 1910; Spranger 1909.

16 AsH 1999.

17 At this point, I refer only to JeIsmann 1996: vol. I; JeIsmann 1996: vol. II; see further JeIsmann/ LUNDGREEN 1987: vol. III; VOM BRUCH 1999; RÜEGg 1999; KRAUS 2008: 69 f.

18 See Flashar 1986; Jecht 2003; Matthiessen 2003; Menze 1992; Quillien 1983; Rehm 1936; Stadler 1959.

19 BOLLENBECK 1996: 147f. 
of temperament," and their "simple wisdom allowing them to live life impulsively and to enjoy it." ${ }^{\prime 20}$ Yet he did not demand the reproduction of the ancient conditions. Instead, he advocated the creative examination of the Greek world with the intention of founding the individual personality on a historical collective character, which thus acquired transhistorical significance.

In the Greek character, as Humboldt explained, one could find "with utmost certainty of outline, all the richness of form, all the diversity of movement and all the intensity and liveliness of colours," the "formal facets of human purpose," which constitute "the appropriate proportion between receptiveness and independence; the deep fusion of the senses and the intellect; the protection of balance and harmony in the sum of all efforts; the tracing back of everything to the real, active life; and the portrayal in detail of every splendour in the whole assembly of nations and of the human race."21 The Greek character in its versatility and harmonic development came closest to the "idea of a perfect human race" (Idee der heilen Menschheit), the "character of mankind in general," "which can be there and should be there in every situation, without taking into consideration individual differences." ${ }^{\prime 22}$

The neo-humanist educational programme that Wilhelm von Humboldt advanced in Prussia and Friedrich Immanuel Niethammer in Bavaria made Greek antiquity, which was viewed as noble and sublime, a central subject of grammar school instruction. The Greek language as a product of the Greek spirit and as an expression of Greek character took absolute precedence, as it was believed that unity and diversity, senses and intellect, object and subject, world and disposition are harmonically connected by it, and that this language it is an individual expression of the mind of the Greek people and its national character: "The Greeks are also distinguished by the peculiarity of a language reflecting brightly and clearly the essence of the entire population. [...] Through the poetic and prose works the liveliness and accuracy of the nation's linguistic meaning stands out, the genuine artistic love and the skill with which it treated an instrument that required greater agility, certainty of tactfulness and sensitivity of feeling, especially because of its perfection." 23

Learning such a complexly structured language was meant not only to improve personal linguistic competence, but also to help the individual educate himself comprehensively and understand the world. By shaping the person, Greek language became an instrument for the appropriation of the world, which allowed one to appreciate the diversity of that world without utilitarian interests. Learning the Greek language, therefore, did not

20 Humboldt, "Das achtzehnte Jahrhundert," GS II, 25 (I, 402f.).

21 Humboldt, "Über den Charakter der Griechen, die idealische und historische Ansicht desselben," GS VII, 613f. (II, 69f.).

22 Humboldt, "Über das Studium des Alterthums, und des griechischen insbesondere," GS I, 265 (II, 9).

23 Humboldt, "Über die Verschiedenheit des menschlichen Sprachbaus und ihren Einfluss auf die geistige Entwicklung des Menschengeschlechtes," GS VI, 112 (III, 145). 
serve to imitate the spoken and written forms of a bygone age, but aimed at the general and harmonic development of individual aptitude in the present. Consequently, education was an end in itself and simultaneously a permanent process of self-perfection: "The true purpose of man - not the one that changing inclinations dictate to him, but the one that the eternal unchanging common sense demands of him - is the highest and most proportioned formation of his powers into a whole." ${ }^{24}$

The university that Humboldt created to advance this purpose was based on an idealised image of the Greeks. His vision evoked the idea of education through Wissenschaft, which was, in turn, characterised by research without a specific purpose, the association of research and teaching, reflection on the whole, and the permanent endeavour to advance knowledge. Wissenschaft, in Humboldt's words, was "something not quite yet found and never totally attainable," which "was to be sought out for its own sake" and had to be practiced in "solitude and independence," namely, independence from political and social constraints. ${ }^{25}$

The search for truth and the striving for discovery for its own sake required an understanding of all fields of human knowledge. In the light of contemporary issues, Humboldt opposed the specialisation and fragmentation of education and Wissenschaft, which led to the world not being understood as a whole anymore. "The mathematician, the naturalist, the artist, and frequently even the philosopher not only begin their work without knowing its true nature and without surveying it in its completeness, but also, later on, only a few of them elevate themselves to a higher point of view and a more general overview of the work." ${ }^{\prime 26}$

Following Friedrich Schiller, Humboldt deployed Greek antiquity as an alternative to the present condition, which was frequently described as inadequate. For "the predominant trait" of the Greeks, he wrote, was "respect for and pleasure at symmetry and equilibrium, wanting to admit the most noble and sublime only there, where this is in harmony with the whole." As a consequence, the "disparity between inner and outer existence that frequently torments the present generation" was simply foreign to their nature. ${ }^{27}$ The wide variety of the different areas of life which made modern man feel so very insecure had not led to contradictions and conflicts in ancient Greece; instead, differences were combined into a unity. This very harmony in the plurality of human existence had made the Greeks the "ideal we ourselves want to be and to which we aspire." ${ }^{28}$

The Greeks demonstrated that striving for education could never end and that it was a lifelong process of self-instruction. Such concepts were directed against the class sys-

24 Humboldt, "Ideen zu einem Versuch die Gränzen der Wirksamkeit des Staates zu bestimmen," GS I, 107 (I, 64).

25 Humboldt, "Über die innere und äußere Organisation der höheren wissenschaftlichen Anstalten in Berlin," GS X, 253, 255 (IV, 257, 259).

26 Humboldt, "Theorie der Bildung des Menschen," GS I, 282f. (I, 234).

27 Humboldt, "Geschichte des Verfalls und Untergangs der griechischen Freistaaten," GS III, 198 (II, 102).

28 Ibid., GS III, 189 (II, 92). 
tem of the ancien régime while sustaining new educational elites that were no longer legitimised by birth and origin, but by performance and education. The ideal of a higher education oriented toward Greek humanity was, in theory, available to all people, "as the most common day labourer and the finest educated person has to be initially made equal in his disposition, if the former is not to become callous unbefitting human dignity and the latter is not to become sentimental, chimerical and eccentric unbefitting the power of man." 29

Yet Humboldt's idea of education was by no means egalitarian. One had to be able to afford an education that served a purpose, but had limited practical usefulness. It was the rising bourgeoisie that could adopt Humboldt's ideal (through Wissenschaft) at the beginning of the nineteenth century. For this reason, the veneration of the Greeks established a central idea of education as a permanent process of self-perfection, which was vital to the cultural identity of middle-class society in Germany. The bourgeois world of the Greeks replaced the aristocratic vision of antiquity, already shaped by the French court's encounter with Rome. Education became the actual and true title of nobility. From that point onward, the sign of bourgeois exclusivity was the sovereign mastery of the Greek language.

\section{Normativity and Historicity: Timeless Magnitude and Paradigmatic Historicity}

The Greeks revealed to Humboldt the "pure humanity of mankind fulfilled for its own sake." They "are to us what their gods were to them." ${ }^{\prime 30}$ The Romans were merely perceived and accepted as conveyors of the Greek heritage. The adulation of the Greeks was accompanied by the debasement of the Roman tradition. "Provided that antiquity implies a form of idealism, the Romans are included only to the extent that it is impossible to separate them from the Greeks." ${ }^{\prime 31}$

Humboldt shared the conviction of his contemporary classicists that to understand oneself one needed to comprehend that which is foreign; and, moreover, that one's own mind was to be discovered and educated in the frame of the debate with the person opposite and as part of the acquisition of another's intellect. In encountering Greece, Humboldt raised a crucial question for the German bourgeoisie: under which circumstances and conditions and with what aim could an individual and a nation appropriate and render accessible foreign traditions? ${ }^{32}$ In responding to this question, he emphasised again the importance of the Greek language, in which the Greek spirit manifested itself in its natu-

29 Humboldt, "Der Königsberger und der Litauische Schulplan," GS XIII, 278 (IV, 189).

30 See also Humboldt, "Über den Charakter der Griechen, die idealische und historische Ansicht desselben," GS VII, 609-616 (II, 65-72).

31 Humboldt, "Geschichte des Verfalls und Untergangs der griechischen Freistaaten," GS III, 197 (II, 101); see further Humboldt, "Über den Charakter der Griechen, die idealische und historische Ansicht desselben," GS VII, 610 (II, 66).

32 See Oesterle 1996: 307. 
ralness, power, and abundance. As he pointedly put it, "all genuine intellectual education" emerged "from the peculiarities of the Attic dialect."

However, it was not only the language that had to be learned. Individuals were meant to grasp Greek culture in its diversity and the Greek character in its totality. While Humboldt in principle granted every nation the opportunity to develop an individual character, he nevertheless argued that only Greek antiquity was of outstanding significance: "Through these traits the Greek character became the ideal of all human existence in as much as it could be maintained that these set out the pure form of human purpose, even if the implementation of this form could have happened in a different way afterwards." ${ }^{34}$

According to Humboldt, the study of such a character has to have a generally remedial effect on human education in every situation and in every era, "as, so to speak, the very same constitutes the basis of the human character in general." ${ }^{\prime 35}$

Humboldt's idealisation of Greek antiquity was a late variant of the Querelle des Anciens et des Modernes, which, however, in the seventeenth century, had conveyed a largely Romano-centric image of antiquity. ${ }^{36}$ Following Winckelmann, who had celebrated the "noble simplicity and calm greatness" of Greek works of art and had demanded the "imitation" (Nachahmung) of the Greeks in order to become great oneself, ${ }^{37}$ Humboldt took delight in the emotionalism of the classical enthusiasm for all things Greek. Nevertheless, he did not speak out in favour of the imitation of the Greek historical paradigm, as this was in his opinion impossible: "To us the Greeks are not simply a useful historical people to know, but an ideal. Their authority over us is of a kind that arises particularly from their inaccessibility. ${ }^{\prime \prime 3}$ Blind imitation could not lead the individual to harmonically develop personal talents. What was needed was the continuous consideration of the idealised image of Hellas, which was not a historical place, but rather a Utopia, a "necessary illusion" (nothwendige Täuschung). Antiquity had passed and the modern world could not be deduced from the old one. ${ }^{39}$ Humboldt did not want to portray the Greeks in their timeless magnitude anymore, but in their paradigmatic historicity. Consequently, Greece became the object of historical research, whose task was to describe the unique individuality of the Greek national character. The modern subject of the Classics - with which Humboldt had become acquainted as a student in Göttingen under Christian Gottlob

33 HAYM 1859: $134 f$.

34 Humboldt, "Über den Charakter der Griechen, die idealische und historische Ansicht desselben," GS VII, 613 (II, 69); see also Humboldt, "Über das Studium des Altertums und des griechischen insbesondere," GS I, 262f. (II, 7f.).

35 Humboldt, "Über das Studium des Altertums, und des griechischen insbesondere," GS I, 275 (II, 19).

36 See also Yímaz 2004.

37 Uhlig 1988: 24.

38 Humboldt, "Über den Charakter der Griechen, die idealische und historische Ansicht desselben," GS VII, 609 (II, 65).

39 See Wilhelm von Humboldt to Goethe, 23 August 1804, cited in Wilhelm von Humboldt, Werke in fünf Bänden (note 1) V, 215-217. 
Heyne and which Friedrich August Wolf, with whom Humboldt corresponded intensively, stood for - was responsible for the research into this individuality. ${ }^{40}$ It could no longer be the sole task of Classics to edit and comment on the traditional texts of antiquity. It was rather necessary for those texts to be subjected to historical analysis and interpretation according to the rules of historical source criticism. Thus, classical philology became an historical discipline. And since antiquity was still regarded as the most distinguished object of historical interest, classical philology considered itself as the first among the historical disciplines. The question surrounding the conditions of the possibility of objective discoveries in history was discussed using ancient topics; and the principles of the newly-constituted hermeneutics were applied to the philological historical analysis of Greek and Latin texts. ${ }^{41}$

As a result, Humboldt was at the forefront of a development that historicised Greek antiquity and relativised its normative function. Over the course of the nineteenth century, the ideals of Wissenschaft and education drifted apart. In later years, Humboldt not only concentrated on researching the ancient world, but also pursued universal historical objectives, at first intending to confirm the uniqueness of the Greek national character by drawing comparisons, and later without any explicit reference to the exceptionality of European antiquity. In his late linguistic studies, he distanced himself from any cultural hierarchy that privileged European antiquity. ${ }^{42}$

August Boeckh and Johann Gustav Droysen continued resolutely on the path set out by Heyne, Wolf and Humboldt, at the end of which came the realisation that the ancient world was only one epoch among others. The significance of their contribution, which initially made the Greeks its primary focus, cannot be underestimated when considering the development of a modern conception of history and its scientific methodology. In a speech to the academy held in 1821 and entitled "On the task of the historian" (Über die Aufgabe des Geschichtsschreibers), Humboldt advocated a historiography which brought to an end the mere enumeration of facts and stressed the powers of the mind and the imagination. These powers, he argued, were vital to successfully discovering the internal coherence of history and the laws of historical development. Humboldt addressed the ideas that structure history and make a fabric out of the material of facts. Ideas are, by their nature, "outside the circle of finitude"; and they prevail in and dominate world history "in all their parts." ${ }^{\text {"33 }}$ So it is the task of the historian, with his ability to imagine and his gift of deduction ${ }^{44}$ to uncover the transcendent ideas as the driving forces of history and to describe their effect in the immanence. "The duty of the historian, in his ultimate, but simplest resolution, is to portray the striving of an idea to win existence in reality. ${ }^{\prime \prime 4}$ In the

40 See HenZE 1966 and MatTSON 1990.

41 See Muhlack 1979, esp. 232-236.

42 See Messling 2008, esp. 227-276.

43 Humboldt, "Über die Aufgabe des Geschichtsschreibers," GS IV, 51f. (I, 600f.).

44 Ibid., GS IV, 37 (I, 587).

45 Ibid., GS IV, $56(\mathrm{I}, 605)$. 
transition from enlightened historiography to historicism, Humboldt did not construct the unity of the past by portraying past events, but by describing ideas that the historian extracts from these events. The creative imagination of the historian was no longer stigmatised, but rather became the true condition of the possibility of historical discoveries.

The ancient paradigm furnished the bourgeoisie with the certainty that the passage of time could be influenced by historiography. The exclusive competence - and task - of historiography was to "enlighten the present about its future and therefore, about the historical moment to which it belongs and which it has to do justice to." ${ }^{1 / 6}$ The citizen could, and had to, learn from antiquity how to exercise political and social responsibility. Historical reflection, which had its origin in Greek antiquity, thus became a central aspect of bourgeois culture.

The fundamental historicisation of the ideas of mankind and the world as well as the unparalleled rise of historically-oriented subjects at universities and in public perception characterised politics, society, and the mentality of the nineteenth-century bourgeoisie. This dynamic process originated in the aestheticising enthusiasm for Greek antiquity, the neo-humanist concept of education, the rational method of textual criticism, and the re-validation of historiography. ${ }^{47}$ Humboldt contributed to the development of hermeneutics, which. for the bourgeois intellectual interpretation, served as a theoretical concept to the study of history and antiquity. ${ }^{48}$

Moreover, the evocation of ancient Greece as an "ideal for comparison" (Ideal zur Vergleichung) resulted in a critical assessment of Christianity, which, as Humboldt explained, was responsible for the decay of taste and scholarly culture in the period from the fourth to the mid-sixteenth centuries. Christianity has worn man down "in such a way that natural rest and undisturbed inner peace were lost to him forever [...]. By splitting his nature, it opposed human sensuality with a pure spirituality and filled man with ideas of poverty, humility and sin that would now never disappear. ${ }^{\prime \prime 49}$ Humboldt contrasted the "barbaric times," which were "very fittingly named the Middle Ages," with the distanced and idealised Greek past. ${ }^{50}$ In doing so, he broke with the idea, which had hitherto dominated the humanist tradition, that pre-Christian and Christian antiquity constituted a unity; in its place he put an exclusively pagan past, the study of which was to bring about the renewal of the present.

Friedrich Paulsen has aptly described the consequences of this move: "The new age found the image of perfection within Hellenism rather than within Christianity: the image of the perfect human being rather than that of God incarnate. [...] Hellenising humanism is a new religion, the philologists are its priests, the universities and schools its temple." ${ }^{\prime \prime 51}$

46 MuHLACK 1998: 276.

47 See NipPerdey 1983: 498-533.

48 See TAEGER 1994: 65-85.

49 Humboldt, "Das achtzehnte Jahrhundert," GS II, 24 (I, 401).

50 Ibid., GS II, 24 (I, 401).

51 Paulsen 1921: 311. 
Humboldt conceptualised a secular educational religion, which expedited the de-Christianisation of society in the bourgeois world and led to a quasi-religious veneration of Hellenism.

\section{Freedom and Education of the Individual: On the Genesis of Bourgeois Society}

Following Herder, Humboldt developed the term individuality in his studies on the ancient world. From the French Revolution, he deduced that in certain historical situations everything depends on individual abilities. The politician who seeks to change the world for the better has to create conditions that allow these abilities to develop freely. The historian, however, has to recognise and portray the individual abilities in their particular manifestation in the past epoch. The historical search for individuality has to be directed toward generality, which nevertheless manifests itself in the actions of individual people, as well as in the language, the nation, and the state. This understanding of individuality emancipated the individual, who was no longer subordinate to a collective, but was understood in his exceptionality as a constituting part of generality. ${ }^{52}$

Every single person was entitled to individual rights and personal freedom if he wanted to develop his talents and strive successfully for the appropriation of the world. Humboldt's demand to raise the individual to be independent, proactive, and self-responsible presupposed individual rights and personal freedom and was directed at the state, which was the only institution that was able to guarantee these rights and this freedom. "For this education freedom is the primary and essential condition. [...] The person educated like this would then have to become part of the state; and the constitution of the state, as it were, would have to measure itself taking him as an example. Only as part of such a struggle would one be certain to hope for a true improvement of the constitution by the nation $[. . .]^{\prime \prime 53}$

Humboldt identified the liberation of the citizen, so as to become a proactive human being, as the foremost purpose of the modern state. Consequently, the state was not allowed to hinder the education of the individual, or intervene in upbringing, religion and morals, but had to accept freedom as the primary and essential condition of education and Wissenschaft. It was necessary, therefore, to restrict the effectiveness of the state. ${ }^{54}$ The "state constitution" (Staatsverfassung) was merely "a necessary means" and "as it is inevitably associated with restrictions of freedom," nothing more than "a necessary evil." 55 Humboldt linked the new idea of the state to the new idea of education. The state was

52 See also MuHLaCK/HeNTSCHKe 1972: 80ff.

53 Humboldt, "Ideen zu einem Versuch die Gränzen der Wirksamkeit des Staates zu bestimmen," GS I, 144 (I, 106).

54 See BenNer 1995: 55-67.

55 Humboldt, "Ideen zu einem Versuch die Gränzen der Wirksamkeit des Staates zu bestimmen," GS I, 236 (I, 212). 
called to take in hand the education of the individual solely for the sake of that person and without pursuing any secondary aims linked to power and interest. At the same time, one would also expect that the new education, which was empowered by its inherent law, would inspire devotion to both the people and the state. ${ }^{56}$

Humboldt advocated the idea of active political participation of citizens concerned and integrated them into his model of a society that constituted itself as a community of citizens capable of controlling its own affairs independently. For Humboldt, though, the place for an individual's free activity was not the state, but the nation. He drew a sharp dividing line between the state and the nation. The state was responsible for internal and external security, while the nation was characterised by the voluntary cooperation of citizens in various areas. The citizen alone could establish the connection between state and nation by engaging in self-confident political activity. The "free interactions among the people of a nation," which "protects all possessions, the longing for which leads the people to form a community, ${ }^{\prime \prime 57}$ anticipated the bourgeois conception of civil sphere that was partly separated from the state. ${ }^{58}$ The purpose of this separation, according to Humboldt, was to secure an area for citizens that would be largely free from state influence, as "the human race" (das Menschengeschlecht) has now "reached a level of culture, from which it could rise higher only by training the individuals. Therefore, all institutions that may hinder this training and force people together in masses are more damaging now than ever before. ${ }^{\prime \prime 59}$

Here, Humboldt put past and present in a productive relationship to one another. Antiquity served as a point of reference, but no return to the ancient state of affairs was intended. In his theoretical considerations on the state, Humboldt left no doubt as to his conviction that the Greek polis and the Roman res publica represented an obsolete model: "Those states were republics, their institutions of this kind were pillars of a free constitution that filled the citizens with enthusiasm, which let the detrimental influence of the restriction of individual freedom be felt less and did less damage to the energy of the character. As a consequence, the citizens enjoyed much greater freedom compared to us; and what they sacrificed they sacrificed to another activity, a share in the government. In our mostly monarchical states, all is completely different."160

In antiquity, no distinction was made between state and society, and the citizen of the ancient city-state subordinated his individual freedom to the public good. Here, Humboldt contrasted the political conditions prevailing in the monarchies of his time with the

56 See SCHNABEL 1948: 410.

57 Humboldt, "Das achtzehnte Jahrhundert," GS I, 236 (I, 212).

58 See further SAUter-BergerHaUSEN 2002 and SPITTA 2004.

59 Humboldt, "Ideen zu einem Versuch die Gränzen der Wirksamkeit des Staates zu bestimmen," GS I, 142f. (I, 105).

60 Ibid., GS I, 142 (I, 104f.). 
historical situation in antiquity. The discussion about the circumstances in antiquity led him to criticise contemporary state and society. ${ }^{61}$

Humboldt's notion of antiquity served to construct and legitimise his idea of a modern state that guaranteed and promoted education and freedom. The study of antiquity had therefore a contemporary, eminently political dimension. The ancient examples explained the necessity to connect, in the present, bourgeois involvement and patriotism with the ideal of individual autonomy. Only such a state would be able to be strong that allowed its citizens personal and institutional freedom and ended the rule of one person over another. Freedom, in Humboldt's words, is "the necessary condition without which even the most soulful action is not able to produce salutary effects." ${ }^{12}$ The concept of a politically active citizen and the model of a bourgeois society that shaped nineteenth-century discourse on liberalism, oriented themselves toward the ideal projection of political activity in the Greek city-states and the Roman Republic. ${ }^{63}$

\section{A Sense of Affinity: The Greeks of the Modern Age}

Humboldt recommended the study of the Greek nation in all its facets. ${ }^{64}$ At first, however, he hardly had any interest in political history, as he thought he could recognise the character of a nation more easily in its literary, scholarly, and artistic achievements. Only the Wars of Liberation against Napoleon made him more sensitive to political events in the past and the present. In 1807, Prussia was devastated after the lost battles against Napoleon's army at Jena and Auerstedt. As an envoy to the Vatican, Humboldt was, at least physically, far removed from the political mood in his homeland. Apart from the linguistic studies he pursued in Rome, in a text that remained fragmentary he addressed a subject of alarming relevance to a Prussian aristocrat: the "History of the decline and fall of the Greek free states." In the foreword that preceded the introduction, Humboldt justified his project: "[I have a] threefold purpose in mind: first of all, to imagine myself in a time where the deeply moving, but always engaging battle of better forces against overpowering violence was fought in an unhappy, but honourable way; secondly, to show that degeneration was only partly to blame for Greece's decline, but that the concealed reason actually was that a Greek person possessed a far too noble, delicate, free and humane nature to establish a political constitution in his time that by necessity limited the

61 See BENNER 1995: $58 \mathrm{f}$.

62 Humboldt, "Ideen zu einem Versuch die Gränzen der Wirksamkeit des Staates zu bestimmen," GS I, $118(\mathrm{I}, 77)$.

63 See also VICK 2007.

64 Humboldt, "Über das Studium des Altertums, und des griechischen insbesondere," GS I, 257 (II, 2). 
individuality; thirdly, to arrive at a point of view, from which it is possible to comfortably survey the old and the new history in its entirety."165

The ways of enquiry that Humboldt had in mind for the history of the decline of Greece constituted nothing less than three different kinds of writing history. From a moving, aesthetic examination of the condition of Greece before the decline he wanted to reach, through the analysis of historical events, a point of view that revealed a universal historical view of past and present.

But what did the history of the decline and fall of the free Greek states demonstrate? Macedonians and Romans, the conquerors of Greece, were barbarians: "The better and nobler part succumbed and the brutish superior strength was victorious." Just as it happens nearly all the time, "barbaric peoples" defeated the "more educated ones," "one-sided, coldly calculating, restless nations their more humane neighbours, who dedicated themselves more faithfully and passionately to the activities of peace." Whoever does not descend "into despair" looks to "regain the freedom on the interior," which has been lost on the exterior. ${ }^{66}$ And victorious Rome formed "in many respects, always the body into which Greece was supposed to breathe the soul.".67

The actualisation of the Greek history of decline is striking and the comparison between Hellas-Germany and Rome-France imposes itself perfectly. The history of post-classical Greece mirrored the most recent humiliation of Prussia by Napoleonic France. At the same time, Humboldt emphasised that Germans and Greeks were especially close: "The Germans have the indisputable merit to have faithfully comprehended Greek education at first and to have felt it deeply [...] Other nations have never been equally happy with this, or at least they have neither in commentaries, nor in translations, nor in imitations, nor eventually (what matters most) in the transmitted spirit of antiquity proven their intimacy with the Greeks in a similar way. A far stronger and closer bond, therefore, connects Germans with Greeks, than with any other, even far closer epoch or nation."

Humboldt goes on to write that Germany bears "an indisputable resemblance to Greece in her language, diversity of efforts, simplicity of mind, as well as her federal constitution and her latest fate." ${ }^{\prime 68}$ Thus, the fundamental arguments for spreading the idea of a Graeco-German relationship were identified. The diversity of the Greek-German national character corresponded to the one-sidedness of the Roman-French one. Humboldt first expressed his view on the "whim about the similarity of the Greeks and the

65 Humboldt, "Geschichte des Verfalls und Untergangs der griechischen Freistaaten," GS III, 171 (II, 73).

66 Ibid., GS III, 173f. (II, 74f.).

67 Ibid., GS III, 181 (II, 86).

68 Ibid., GS III, 185f. (II, 88f.). See also Wilhelm von Humboldt to Johann Georg Schweighäuser (ed. Albert Leitzmann, Jena 1934: 42): "At the same time I cannot deny that I want to erect a memorial to the poor, shattered Germany, as, according to my long felt conviction, only when the German spirit is imbued with the Greek one, we have something, in which the human race can advance without standing still." 
Germans" in passing in a letter to Schiller dated 22 September $1795 .{ }^{69}$ He repeated his idea that a "sense of affinity" existed between Germans and Greeks in other letters, until he developed this point fully in his "History of the decline and fall of the Greek free states" (1807). Humboldt transformed the epochal comparison between antiquity and modernity, formulated in previous centuries, into a dual cultural comparison: on the one hand, between ancient Greece and ancient Rome; on the other, between the cultural nation of Germany, which was equated with Greece, and the nation-state of France, which he regarded as being in the Roman tradition. There was a need to respond to the military defeat of Prussia and to Napoleon's political triumph not only by means of educational, but also by means of cultural policy. The message that Humboldt promulgated in 1807 was that the barbaric "subjugator" was to be overcome culturally. ${ }^{70}$

Following Herder and German idealism's reception of antiquity, Humboldt propagated the concept of a culturally-defined nation that renounces state integration by having cultural cohesion at its disposal. The idea of political unity was replaced by a consciousness of cohesion based on a shared cultural ground, which in turn substantiated the intellectual superiority of the politically fragmented nation. Humboldt's actualisation of the dichotomy that existed between the cultural nation of Greece and the nation-state of Rome compensated for the Prussian political and military defeats and the dissolution of the Holy Roman Empire.

Humboldt thus invented a tradition that set forth the creation of a collective identity. Imagining the Greek past provided the German bourgeoisie with a welcome alternative to the Franco-Latin cultural hegemony in Europe. The Prussian aristocrats' national myth of the Greeks was directed against France and the "Gallomania" of the German nobility, against the absolutist state and its class system. This myth, which was spread by grammar schools and universities in Germany, was a key instrument in the protection of national identity and in the process of coming to terms with the present. The new myth of the relationship between Germans and Greeks, which originated in a certain historical situation, became part of the bourgeois endowment of national collective life with meaning and reinforced the idea of being a citizen of a superior cultural nation. ${ }^{71}$

\section{Epilogue}

The study of ancient, especially Greek, history in nineteenth-century Germany established new conceptions of upbringing, education and Wissenschaft, but also of nation, state and society. Interpretations of the present and the past were closely interlinked. The present was not appraised on the grounds of antiquity. On the contrary, a utopian vision of the ancient past, constituted in the present, was projected back onto the past. Hum-

69 See also LANDFESTER 1996: $208 \mathrm{f}$.

70 See FuhrmanN 1979; Lohse 1997; RÜEgG 1985; RÜEgG 1975.

71 LANDFESTER 1996: 211. 
boldt did not propagate a timeless model that was to be imitated, but imagined an ideal place, the examination of which was meant to help overcome the status quo.

The bourgeois conception of history, the rise of the historical Wissenschaften, and the establishment of a theory of historical hermeneutics aiding the creation of bourgeois identity had their origin in the study of antiquity. Greece (and to a lesser extent also Rome) was a pivotal point of reference and comparison for the definition of education, which was seminal to bourgeois society as a permanent process of self-perfection, for the description of the relationship between freedom and education, for the link between individual, society, and state, and finally for the discussion of the principles of social organisation and structure. In the end, the idea of the cultural nation was developed through the dialogue with Greek antiquity. The idealised Greeks became a permanent part of German national culture, in which some scholars identified a "Tyranny of Greece over Germany."72

The image of the Greeks supported the productive comparison between modernity and classical antiquity. Humboldt advocated no unified and affirmative position regarding antiquity. Normativity and historicity characterised his vision of the past. His evocations of antiquity were critical of society and of contemporary issues. The absolutist world of men of estates was to be overcome for good and bourgeois social forms were to be realised. To Humboldt, education was the basis for a comprehensive renewal of state and society; the identity of modern man was based on education. His ambitious concept of reform was applied to schools and universities. It made the German university an internationally effective paragon of a modern educational policy and instituted the rise of the historical Wissenschaften. Humboldt's ideal of antiquity was central to this process: it constituted the foundation for the study of the classics in the context of educational reforms that sustained nineteenth-century bourgeois culture. The emancipatory potential of Humboldt's image of antiquity, however, quickly dissipated: it was feared that young people, by showing enthusiasm for Greek antiquity, could infect themselves with republican ideas. In addition, there was competition from research into Germanic culture and the Middle Ages, inspired by romanticism. ${ }^{73}$

Humanist education not only offered an idea of freedom that was juxtaposed to the constraints of state and society; it also advocated taking refuge in a form of inwardness, which counteracted the bourgeois faith in progress, and intensified the dichotomy between "culture" and "economy," "spirit" and "materialism.".74 Still, throughout the shaping of the German empire, an increasingly superficial concept of education came to be the basis of authoritarian institutions, which applied drill and routine to grammar schools. Contentment was attained by drumming in the verbs ending in $-\mu$. In the class society of the nineteenth century, the content of education no longer counted. What was important was the use of specific educational methods that could be used as effective instruments of exclusion. In universities, classical education was triumphant and transformed Grae-

72 BUTLER 1935.

73 See MaRChand 2004.

74 See ULF 2006. 
co-Roman antiquity into an absolute - with a diminishing interest in the Middle East, and a neglect of the history of early Christianity.

At the same time, the historicisation of antiquity marked the end of the idealised vision of the ancients. Humboldt and his contemporaries never left any doubt as to their conviction that Greek culture is the basis of a humanist education. Such a normative conception of antiquity was alien to the methodically professionalised study of antiquity, whose modern realism destroyed the special position of the Greeks upon which the German bourgeois intellectual had come to rely. After the mid-nineteenth century, individual scholars, mostly academic outsiders such as Friedrich Nietzsche, opposed the established forms of classical education. They criticised a Wissenschaft of antiquity that only amassed highly specialised knowledge and tried, alluding to Humboldt, to preserve European antiquity as a normative model that was intended to have an educational function. Their efforts were characterised by a deeply rooted cultural pessimism implying a quest for far-reaching social and political changes. ${ }^{75}$ Yet the profound shifts in bourgeois culture in the transition from the nineteenth to the twentieth centuries and the manifest competitiveness of different lifestyles and kinds of behaviour allowed only a minority to continue to believe in the educational and emancipatory potential of classical Greece.

\section{Bibliography}

Ash, Mitchell G. (ed.) (1999), Mythos Humboldt. Vergangenheit und Zukunft der deutschen Universitäten, Vienna.

Benner, Dietrich (1995), Wilhelm von Humboldts Bildungstheorie. Eine problemgeschichtliche Studie zum Begründungszusamenhang neuzeitlicher Bildungsreform, 2nd Edition, Weinheim/Munich.

Berglar, Peter (2003), Wilhelm von Humboldt, 9th Edition, Reinbek near Hamburg.

Bollenbeck, Georg (1996), Bildung und Kultur. Glanz und Elend eines deutschen Deutungsmusters, Frankfurt/M.

Butler, Eliza (1935), The Tyranny of Greece over Germany, Cambridge [reprint Boston 1958; abridged German translation Deutsche im Banne Griechenlands, Berlin 1948].

Conze, Werner, Jürgen Kocka, and Reinhart Koselleck et al. (eds.) (1985-1992), Bildungsbürgertum im 19. Jahrhundert, 4 volumes, Stuttgart.

Flashar, Hellmut (1986), "Wilhelm von Humboldt und die griechische Literatur," in Bernfried Schlerath (ed.), Wilhelm von Humboldt. Vortragszyklus zum 150. Todestag, Berlin/New York, 82-100.

Fuhrmann, Manfred (1979), "Die Querelle des Anciens et Modernes, der Nationalismus und die deutsche Klassik," cited from ibid., Brechungen. Wirkungsgeschichtliche Studien zur antik-europäischen Bildungstradition, Stuttgart 1982, 129-149.

Hahn, Hans-Werner and Dieter Hein (eds.) (2005), Bürgerliche Werte um 1800. Entwurf - Vermittlung Rezeption, Cologne.

Haym, Rudolf (ed.) (1859), Wilhelm von Humboldts Briefe an Friedrich Gottlieb Welcker, Berlin.

Hein, Dieter and Andreas Schulz (eds.) (1996), Bürgerkultur im 19. Jahrhundert. Bildung, Kunst und Lebenswelt, Munich.

Henze, Clemens (1966), Wilhelm von Humboldt und Christian Gottlob Heyne, Ratingen.

75 See LANDFESTER 1988. 
Jaeger, Friedrich (1994), Bürgerliche Modernisienungskrise und historische Sinnbildung. Kulturgeschichte bei Droysen, Burckhardt und Max Weber, Göttingen.

Jecht, Dorothea (2003), Die Aporie Wilhelm von Humboldts. Sein Studien- und Sprachprojekt zwischen Empirie und Reflexion, Hildesheim.

Jeismann, Karl-Ernst (1996), Das preußische Gymnasium in Staat und Gesellschaft, vol. I: Die Entstehung des Gymnasiums als Schule des Staates und der Gebildeten, 1787-1817, 2nd Edition, Stuttgart.

Jeismann, Karl-Ernst (1996), Das preußische Gymnasium in Staat und Gesellschaft, vol. II: Höhere Bildung zwischen Reform und Reaktion, 1817-1859, Stuttgart.

Jeismann, Karl-Ernst and Peter Lundgreen (eds.) (1987), Handbuch der deutschen Bildungsgeschichte, vol. III: 1800-1870. Von der Neuordnung Deutschlands bis zur Gründung des Deutschen Reiches, Munich.

Kaehler, Siegfried A. (1927), Withelm von Humboldt und der Staat. Ein Beitrag zur Geschichte deutscher Lebensgestaltung um 1800, Munich/Berlin.

Kocka, Jürgen (ed.) (1987), Bürger und Bürgerlichkeit im 19. Jahrhundert, Göttingen.

Kocka, Jürgen (ed.) (1995), Bürgertum im 19. Jahrhundert, 3 volumes, Göttingen.

Kraus, Hans-Christof (2008), Kultur, Bildung und Wissenschaft. Im 19. Jahrhundert, Munich.

Landfester, Manfred (1988), Humanismus und Gesellschaft. Untersuchungen zur politischen und gesellschaftlichen Bedeutung der humanistischen Bildung in Deutschland, Darmstadt.

Landfester, Manfred (1996), "Griechen und Deutsche: Der Mythos einer 'Wahlverwandtschaft," in Helmut Berding (ed.), Mythos und Nation. Studien zur Entwicklung des kollektiven Bewußsseins in der Neuzeit, vol. III, Frankfurt/M., 198-219.

Lepsius, M. Rainer (1987), "Zur Soziologie des Bürgertums und der Bürgerlichkeit," in Jürgen Kocka (ed.), Bürger und Bürgerlichkeit im 19. Jahrhundert, Göttingen, 79-100.

Lohse, Gerhard (1997), "Die Homerrezeption im 'Sturm und Drang' und deutscher Nationalismus im 18. Jahrhundert," International Journal of the Classical Tradition 4, 2, Fall, 195-231.

Lundgreen, Peter (ed.) (2000), Sozial- und Kulturgeschichte des Bürgertums. Eine Bilanz des Bielefelder Sonderforschungsbereichs (1986-1997), Göttingen.

Marchand, Suzanne L. (1996), Down from Olympus: Archaeology and Philhellenism in Germany, 17501970, Princeton.

Matthiessen, Kjeld (2003), "Wilhelm von Humboldt und das Studium des Altertums," in Gerhard Lohse (ed.), Aktualisierungvon Antike und Epochenbewußstsein. Erstes Bruno Snell-Symposion der Universität Hamburg am Europa-Kolleg, Leipzig, 179-197.

Mattson, Philip (ed.) (1990), Withelm von Humboldt. Briefe an Friedrich August Wolf, Berlin.

Maurer, Michael (1996), Die Biographie des Bürgers. Lebensformen und Denkweisen in der formativen Phase des deutschen Bürgertums (1680-1815), Göttingen.

Menze, Clemens (1975), Die Bildungsreform Wilhelm von Humboldts, Hanover.

Menze, Clemens (1992), "Das griechische Altertum und die deutsche Bildung aus der Sicht Wilhelm von Humboldts," in Fritz-Peter Hager et. al. (eds.), Aspects of Antiquity in the History of Education, Hildesheim, 45-60.

Messling, Markus (2008), Pariser Orientlektüren. Zu Withelm von Humboldts Theorie der Schriften, Paderborn.

Muhlack, Ulrich and Ada Hentschke (1972), Einfühnng in die Geschichte der Klassischen Philologie, Darmstadt.

Muhlack, Ulrich (1979), "Zum Verhältnis von Klassischer Philologie und Geschichtswissenschaft im 19. Jahrhundert," in Hellmut Flashar et al. (eds.), Philologie und Hermeneutik im 19. Jahrhundert. Zur Geschichte und Methodologie der Geisteswissenschaften, vol. I, Göttingen, 225-239.

Muhlack, U1rich (1998), "Johann Gustav Droysen: Das Recht der Geschichte," in Sabine Freitag (ed.), Die 48er, Munich, 263-276.

Neugebauer, Wolfgang (1990), "Bildungsreformen vor Wilhelm von Humboldt. Am Beispiel der Mark Brandenburg," Jahrbuch für Brandenburgische Landesgeschichte 41, 26-249. 
Nipperdey, Thomas (1998), Deutsche Geschichte 1800-1918, 3 vols., Munich.

Oesterle, Günter (1996), “Kulturelle Identität und Klassizismus. Wilhelm von Humboldts Entwurf einer allgemeinen und vergleichenden Literaturerkenntnis als Teil einer vergleichenden Anthropologie," in Bernhard Giesen (ed.), Nationale und kulturelle Identität. Studien zur Entwicklung des kollektioen Bewuptseins in der Neuzeit, Frankfurt/M., 304-349.

Paletschek, Sylvia (2001), "Verbreitete sich ein 'Humboldtsches Modell' an den deutschen Universitäten im 19. Jahrhundert?", in Rainer Chr. Schwinges (ed.), Humboldt International. Der Export des deutschen Universitätsmodells im 19. und 20. Jahrhundert, Basel, 75-104.

Paletschek, Sylvia (2002), “Die Erfindung der Humboldtschen Idee. Die Konstruktion der deutsche Universitätsidee in der ersten Hälfte des 20. Jahrhunderts," in Historische Anthropologie. Kultur - Gesellschaft-Alltag 10, 183-205.

Paulsen, Friedrich (1921), Geschichte des gelehrten Unterrichts auf den deutschen Schulen und Universitäten vom Ausgang des Mittelalters bis zur Gegenwart - mit besonderer Rücksicht aufden klassischen Unterricht, vol. III, 3rd Edition, Leipzig.

Quillien, Jean (1983), G. de Humboldt et la Grèce. Modèle et histoire, Lille.

Rebenich, Stefan (2011), "The Making of a Bourgeois Antiquity: Wilhelm von Humboldt and Greek History," in Alexandra Lanieri (ed.), The Western Time of Ancient History: Historiographical Encounters with the Greek and Roman Past, Cambridge, 119-137.

Rehm, Walter (1936), Griechentum und Goethezeit. Geschichte eines Glaubens, Berne/Munich [4th Edition 1968].

Rüegg, Walter (1975), "Die Antike als Leitbild der deutschen Gesellschaft im 19. Jahrhundert," cited from ibid., Bedrohte Lebensordnung. Studien zur humanistischen Soziologie, Zurich/Munich 1978, 93105.

Rüegg, Walter (1985), "Die Antike als Begründung des deutschen Nationalbewußtseins," in Wolfgang Schuller (ed.), Antike in der Moderne, Constance, 267-287.

Rüegg, Walter (1999), "Ortsbestimmung. Die Königlich Preußische Akademie der Wissenschaften und der Aufstieg der Universitäten in den ersten zwei Dritteln des 19. Jahrhunderts," in Jürgen Kocka (ed.), Die Königlich Preußische Akademie der Wissenschaften zu Berlin im Kaiserreich, Berlin, 23-47.

Sauter-Bergerhausen, Christina (2002), "Vom 'blutigen Krieger' zum 'friedlichen Pflüger.' Staat, Nation und Krieg in Wilhelm von Humboldts 'Tdeen zu einem Versuch, die Gränzen der Wirksamkeit des Staats zu bestimmen,"' Forschungen zur Brandenburgischen und Preußischen Geschichte 12, 211-262.

Schnabel, Franz (1948), Deutsche Geschichte im 19. Jahrhundert, vol. I, 4th Edition, Freiburg i.Br.

Schulz, Andreas (2005), Lebenswelt und Kultur des Bürgertums im 19. und 20. Jahrhundert, Munich.

Spitta, Dietrich (2004), Die Staatsidee Wilhelm von Humboldts, Berlin.

Spranger, Eduard (1909), Wilhelm von Humboldt und die Humanitätsidee, Berlin [21928].

Spranger, Eduard (1910), Wilhelm von Humboldt und die Reform des Bildungswesen, Berlin [2nd Edition 1960, 3rd Edition 1965, Tübingen].

Stadler, Peter Bruno (1959), Wilhelm von Humboldts Bild der Antike, Einsiedeln.

Sünderhauf, Esther S. (2004), Griechensehnsucht und Kulturkritik. Die deutsche Rezeption von Winckelmanns Antikenideal 1840-1945, Berlin.

Sweet, Paul Robinson (1980), Wilhelm von Humboldt. A Biography, vol. II, Ohio.

Uhlig, Ludwig (ed.) (1988), Griechenland als Original. Winckelmann und seine Rezeption in Deutschland, Tübingen.

Ulf, Christoph (2006), "Elemente des Utilitarismus im Konstrukt des 'Agonalen,'” Nicephorus 19, 67-79.

Vick, Brian (2007), "Of Basques, Greeks, and Germans: Liberalism, Nationalism, and the Ancient Republican Tradition in the Thought of Wilhelm von Humboldt," Central European History 40, 653-681.

Vierhaus, Rudolf (ed.) (1981), Bürger und Bürgerlichkeit im Zeitalter der Aufklärung, Heidelberg. 
vom Bruch, Rüdiger (1999), "Langsamer Abschied von Humboldt? Etappen deutscher Universitätsgeschichte 1810-1945," in Mitchell G. Ash (ed.), Mythos Humboldt. Vergangenheit und Zukunft der deutschen Universitäten, Vienna, 29-57.

vom Bruch, Rüdiger (2001), "Zur Gründung der Berliner Universität im Kontext der deutschen Universitätslandschaft um 1800," in Gerhard Müller, Klaus Ries and Paul Ziche (eds.), Die Universität Jena. Tradition und Innovation um 1800, Stuttgart, 63-77.

von Humboldt, Wilhelm (1903-1936), Gesammelte Schriften, vol. 1-17 published by the Royal Prussian Academy of Sciences (Königlich Preußische Akademie der Wissenschaften), Berlin [reprint 1967/68].

von Humboldt, Wilhelm (1960-1981), Werke in fünf Bänden, ed. A. Flitner and K. Giel, Darmstadt [various reprints].

Walther, Gerrit (1998), "Adel und Antike. Zur politischen Bedeutung gelehrter Kultur für die Führungselite der Frühen Neuzeit," Historische Zeitschrift 266, 359-385.

Wehler, Hans-Ulrich (1996), Deutsche Gesellschaftsgeschichte, vol. I: Vom Feudalismus des Alten Reiches bis zur defensiven Modernisierung der Reformära 1700-1815, 3rd Edition, Munich.

Wehler, Hans-Ulrich (1996), Deutsche Gesellschaftsgeschichte, vol. II: Von der Reformära bis zur industriellen und politischen "Deutschen Doppelrevolution" 1815-1848/49, 3rd Edition, Munich.

Yilmaz, Levent (2004), Le temps moderne. Variations sur les Anciens et les contemporains, Paris. 